\title{
PENGENDALIAN E. coli DENGAN BAKTERI ASAM LAKTAT (BAL) TERENKAPSULASI TERHADAP PENAMPILAN AYAM BROILER
}

\author{
(Control E. coli with Lactic Acid Bacteria (LAB) Appearance on Encapsulated \\ Broiler Chickens)
}

\author{
Nurul Hasanah Silalahi ${ }^{1}$, Ma'ruf Tafsin ${ }^{2}$ dan Nevy Diana Hanafi ${ }^{2}$ \\ 1. Mahasiswa Program Studi Peternakan Fakultas Pertanian Universitas SumateraUtara \\ 2. Staf Pengajar Program Studi Peternakan Fakultas Pertanian Universitas Sumatera Utara
}

\begin{abstract}
Control of E. coli with lactic acid bacteria (LAB) Encapsulated will improve the appearance of the broiler. The study aims to find out the effect of controlling E.coli by encapsulated lactic acid bacteria (LAB) on feed intake, body weight gain broiler chickens, feed conversion ratio, and index performance of broiler chickens. This research was conducted at the Laboratory of Animal Biology Faculty of Agriculture, University of North Sumatra in October 2014 - November 2014. The design used in this research is completely randomized design (CRD) with four treatments and five replications. This study used 100 broiler chickens with an average initial weight of $37.749 \mathrm{~g} \pm 1.125$. The treatment consisted of $P O A=($ control $), P O B=$ control + E.coli infection, $P 1=$ E.coli infection + lactic acid bacteria $(L A B)$ without encapsulation, $P 2=$ E.coli infection + lactic acid bacteria $(L A B)$ encapsulated. The results showed that the average feed intake for treatment POA, POB, $P 1$ and $P 2$ were 585.61, 575.17, 561.19 and 569.19 (g/head/week). Respectively Body weight gain 364.01, 357.90, 361.74 and 378.90. Feed conversion, respectively 1.61, 1.62, 1.55 and 1.50. Index performance respectively 318.80, 313.12, 332.78 and 360.53. Statistic analysis showed that additive encapsulated LAB give no significant effect $(P>0.05)$ on feed intake, but provides highly significant effect $(P<0.01)$ on increase weight gain agencies broilers and broiler performance index, feed conversion as well. The conclusion of this study Impact of the used by encapsulated lactic acid bacteria $(L A B)$ very significant when done through challenge test E.coli infection in broiler chickens.
\end{abstract}

Keywords: Control of E.coli, Lactic Acid Bacteria (LAB), Encapsulation, Peformans, broiler chicken.

\section{ABSTRAK}

Pengendalian E. coli dengan bakteri asam laktat (BAL) terenkapsulasi akan meningkatkan penampilan pada ayam broiler. Penelitian bertujuan untuk melihat pengaruh pengendalian E. coli dengan bakteri asam laktat (BAL) terenkapsulasi terhadap konsumsi pakan, pertambahan bobot badan (PBB) ayam broiler, konversi pakan, dan indeks performans ayam broiler. Penelitian ini dilaksanakan di Laboratorium Biologi Ternak Jl. Dr. Ahmad Sofyan Fakultas Pertanian Universitas Sumatera Utara pada bulan Oktober 2014 - November 2014. Rancangan yang digunakan dalam penelitian ini adalah rancangan acak lengkap (RAL) dengan 4 perlakuan dan 5 ulangan. Penelitian ini menggunakan 100 ekor ayam broiler dengan bobot awal rata-rata 37,749 g $\pm 1,125$. Perlakuan terdiri atas $\mathrm{P} 0 \mathrm{~A}=($ kontrol $), \mathrm{P} 0 \mathrm{~B}=\left(\right.$ kontrol + infeksi E.coli 1 x $\left.10^{5} \mathrm{CFU}\right), \mathrm{P} 1=($ infeksi + bakteri asam laktat (BAL) tanpa enkapsulasi), P2 = (infeksi + bakteri asam laktat (BAL) terenkapsulasi). Hasil penelitian menunjukan rataan konsumsi secara berturut-turut P0A, P0B, P1 dan P2 yaitu 585,61, 575,17, 561,19 dan 569,19 (g/ekor/minggu). Pertambahan bobot badan (PBB) secara berturut-turut 364,01, 357,90, 361,74 dan 378,90. Konversi ransum secara berturut-turut 1,61, 1,62, 1,55 dan 1,50. Indeks performans secara berturut-turut $318,80,313,12,332,78$ dan 360,53. Hasil analisa keragaman menunjukan bahwa pengendalian $E$. coli dengan bakteri asam laktat (BAL) terenkapsulasi memberikan pengaruh tidak berbeda nyata $(\mathrm{P}>0,05)$ terhadap konsumsi pakan, namun memberikan pengaruh berbeda sangat nyata $(\mathrm{P}<0,01)$ terhadap peningkatan pertambahan bobot badan (PBB) ayam broiler, indeks performans ayam broiler, serta konversi pakan. Kesimpulan dari penelitian ini penampilan ayam broiler terlihat ketika dilakukan uji tantang (pemberian infeksi E. coli).

Kata kunci : Pengendalian E. coli, Bakteri Asam Laktat (BAL), Enkapsulasi,Peformans, Ayam broiler. 


\section{PENDAHULUAN}

Kurangnya perhatian peternak ayam broiler terhadap penyakit yang ditimbulkan oleh bakteri Escherichia coli (E. coli) pada ayam broiler, serta pemakaian antibiotik yang sering dilakukan dapat mengakibatkan residu pada ternak dan konsumen yang mengkonsumsi ternak tersebut akan menyebabkan penyakit juga menimbulkan resistensi bakteri pathogen. Untuk itu digunakan bakteri asam laktat (BAL) sebagai probiotik di dalam pakan ternak, selain mampu memproduksi asam laktat, BAL juga dapat menghasilkan komponen antimikroba yang dapat menghambat pertumbuhan mikroorganisme yang merugikan hidup inang seperti bakteri E. coli.

Peranan probiotik sebagai bahan aditif pemacu pertumbuhan growth promoter sudah terbukti dapat digunakan. Manfaat langsung dari probiotik tersebut bagi ternak adalah antara lain meningkatkan nafsu makan, menyediakan unsur nutrisi dan membantu proses pencernaan makanan serta menghambat perkembangan bakteri pathogen. Selain itu, Cavazzoni et al. (1998) melaporkan probiotik Bacillus coagulans dapat mempertinggi laju pertumbuhan ayam broiler.

Bakteri asam laktat (BAL) salah satunya terdapat pada usus bagian bawah manusia atau ternak. BAL ini bermanfaat bagi kesehatan dan produksi ternak, karena meningkatkan absorbsi terhadap nutrien tertentu, menghilangkan gejala laktosa intoleran, mereduksi serum kolesterol, meningkatkan motilitas usus, efek anti kanker, inaktivasi enterotoksin dari mikrobia pathogen dan menstimulasi sistem kekebalan tubuh.

Pemanfaatan BAL tidak dapat diberikan secara langsung pada ternak unggas. Pemberian langsung dikhawatirkan menurunkan viabilitas BAL karena derajat keasaman (pH) saluran pencernaan yang bervariasi dan BAL tidak mampu hidup pada target organ yang diinginkan. Oleh karena itu perlu adanya teknologi yang dapat melindungi BAL seperti teknologi kapsulasi (Harahap, 2011).

Enkapsulasi merupakan salah satu teknik untuk mempertahankan komposisi suatu bahan yang diubah penampilannya menjadi partikel padat dengan melapisi bahan atau kombinasi bahan tersebut oleh bahan lainnya. Bahan ini terlindungi dari reaksi kondisi lingkungan yang merugikan yang dapat merusak melalui bahan tersebut (Hogan, 2001). Teknologi ini berperan dalam melindungi bahan inti dari lingkungan yang merugikan. Berdasarkan pemikiran diatas diperlukan adanya penelitian untuk mengendalikan E. coli dengan bakteri asam laktat (BAL) terenkapsulasi terhadap penampilan ayam broiler. 


\section{BAHAN DAN METODE PENELITIAN}

\section{Tempat dan Waktu Penelitian}

Penelitian dilaksanakan di Laboratorium Biologi Ternak Program Studi Peternakan Fakultas Pertanian Universitas Sumatera Utara, JL. A. Sofyan No. 3 Kampus Universitas Sumatera Utara, Medan. Penelitian akan berlangsung selama 5 minggu dimulai dari bulan Oktober hingga pertengahan November 2014.

\section{Bahan dan Alat Penelitian}

Ayam broiler fase day old chick (DOC) sebanyak 100 ekor dengan bobot badan $37.749 \mathrm{~g} \pm 1.125$, bakteri asam laktat (BAL) perlakuan terdiri atas bakteri asam laktat (BAL) tanpa enkapsulasi, bakteri asam laktat (BAL) terenkapsulasi, isolat E. coli, pakan komersil.

Kandang individu dengan ukuran 50 x 100 x $60 \mathrm{~cm}$ sebanyak 20 petak, timbangan digital kapasitas $3 \mathrm{~kg}$ dengan kepekaan $0,1 \mathrm{~g}$, tempat pakan dan tempat minum pada tiap kandang dengan total sebanyak 20 unit.

\section{Metode Penelitian}

Penelitian ini akan menggunakan metode uji tantang yakni peneliti akan menginangkan bakteri $E$. colipada ternak ayam broiler dan diberi perlakuan sehingga dapat diketahui pertumbuhan dan perkembangan bakteri E. coli terhadap perlakuan yang diberikan, apakah perlakuan yang diberikan dapat menghambat pertumbuhan E. coli pada inangnya atau tidak.

Rancangan penelitian yang akan digunakan adalah rancangan acak lengkap (RAL) non faktorial yang terdiri atas 4 perlakuan dan 5 ulangan. Adapun perlakuan yang akan diberikan dan akan diteliti adalah sebagai berikut;

$\mathrm{P} 0 \mathrm{~A}=$ kontrol tanpa infeksi

$\mathrm{POB}=$ kontrol + infeksi E.coli

$\mathrm{P} 1=$ infeksi $E$. coli + bakteri asam laktat (BAL) tanpa enkapsulasi

$\mathrm{P} 2=$ infeksi E. coli + bakteri asam laktat (BAL) terenkapsulasi

E. coli yang digunakan berkisar $\left(6 \times 10^{8} \mathrm{CFU} / \mathrm{ml}\right)$, sedangkan bakteri asam laktat (BAL) terenkapsulasi maupun tanpa enkapsulasi yang digunakan berkisar $\left(1,45 \times 10^{9} \mathrm{CFU} / \mathrm{g}\right)$. Penambahan BAL ke dalam pakan sebesar 3g/1000g pakan $\left(4,35 \times 10^{6} \mathrm{CFU} / \mathrm{g}\right)$.

Metode linier rancangan acak lengkap (RAL) dengan rumus matematika: 


$$
Y_{i j}=+\sigma i+€_{i j}
$$

Keterangan:

$\mathrm{Y}_{\mathrm{ij}} \quad=$ Respon atau nilai pengamatan dari perlakuan ke-i dan ulangan ke- $\mathrm{j}$

$\mathrm{i} \quad=1,2,3 \ldots=$ perlakuan

$\mathrm{j} \quad=1,2,3 \ldots=$ ulangan

$=$ Nilai tengah umum

$\sigma \mathrm{i} \quad=$ Pengaruh perlakuan ke-i

$€_{\mathrm{ij}} \quad=$ Pengaruh galat (Experimental Error)

\section{Analisis Data}

Data yang diperoleh, dianalisis menggunakan analisis ragam (Anova), apabila diantara perlakuan terdapat pengaruh nyata maka akan dilanjutkan dengan menggunakan Uji Beda Jarak Duncan (BNJD).

\section{Parameter Penelitan}

1. Konsumsi pakan

Dihitung setiap hari (24 jam) yaitu pada pukul 08.00 WIB setiap hari.

Dengan rumus sebagai berikut :

Konsumsi pakan $=$ Pakan yang diberikan - Pakan sisa

2. Pertambahan bobot badan (PBB)

Dihitung seminggu sekali pada pukul 08.00 WIB. Dengan rumus sebagai berikut :

Pertambahan bobot badan $($ PBB $)=$ Bobot badan akhir - Bobot badan awal

3. Konversi pakan

Dihitung setiap hari (24 jam) yaitu pada pukul 08.00 WIB setiap pagi.

Dengan rumus sebagai berikut :

Konversi pakan $=\underline{\text { Konsumsi pakan }}$ PBB

4. Indeks penampilan (IP)

Dihitung setelah panen yaitu umur 35 hari ayam broiler.

Indeks penampilan (IP) (Acros, 2009) dapat dihitung dengan rumus:

$\mathrm{IP}=\underline{\text { Mortalitas (M) } \times \text { Live Weight in } \mathrm{kg}(\mathrm{BB})} \times 100$ Age in Days (U) x FCR

Cara mengukur atau menghitung kelima parameter prestasi pemeliharaan ayam broiler sebagai berikut :

- Parameter Bobot Badan/Body Weight (BW) dapat dihitung berdasarkan perbandingan antara bobot timbang (kg) dengan jumlah ayam (ekor). 
- Konversi Pakan/Feed Conversiaon Ratio (FCR) dapat dihitung berdasarkan perbandingan antara jumlah konsumsi pakan $(\mathrm{kg})$ dengan bobot badan $(\mathrm{kg})$ ayam.

- Rata-rata Umur (U) dapat dihitung berdasarkan perbandingan antara jumlah ayam panen (ekor) dengan total ayam terpanen (ekor) dikalikan dengan umur pelihara.

- Tingkat Kematian/Mortalitas (M) dapat dihitung berdasarkan perbandingan antara jumlah ayam mati dengan populasi awal dikalikan dengan 100.

- Nilai Produk/Indeks Penampilan (IP) dapat dihitung berdasarkan perbandingan antara 100 dikurangmortalitas dikali bobot badan dengan konversi pakan dikali umur selanjutnya dikali dengan 100 (Jatmiko, 2006).

\section{HASIL DAN PEMBAHASAN}

Hasil penelitian diperoleh dari konsumsi pakan, pertambahan bobot badan dan konversi pakan, serta indeks penampilan (IP) yang diperoleh selama penelitian.

Rekapitulasi hasil penelitian dapat dilihat pada Tabel 1.

Tabel 1. Rekapitulasi hasil penelitian

\begin{tabular}{|c|c|c|c|c|}
\hline \multirow[b]{2}{*}{ Perlakuan } & \multicolumn{4}{|c|}{ Parameter } \\
\hline & $\begin{array}{l}\text { Konsumsi Pakan } \\
\text { (g/ekor/minggu) }\end{array}$ & $\begin{array}{c}\text { PBB } \\
\text { (g/ekor/minggu) }\end{array}$ & $\begin{array}{l}\text { Konversi Pakan } \\
\text { (g/ekor/minggu) }\end{array}$ & $\begin{array}{c}\text { Indeks } \\
\text { Penampilan }\end{array}$ \\
\hline $\mathrm{P} 0 \mathrm{~A}$ & $585,61^{\mathrm{tn}} \pm 34,39$ & $364,01^{\mathrm{B}} \pm 6,96$ & $1,61^{\mathrm{A}} \pm 0,08$ & $318,80^{\mathrm{BC}} \pm 18,87$ \\
\hline P0B & $575,17^{\mathrm{tn}} \pm 6,73$ & $357,90^{\mathrm{B}} \pm 4,93$ & $1,62^{\mathrm{A}} \pm 0,02$ & $313,12^{\mathrm{C}} \pm 10,83$ \\
\hline $\mathrm{P} 1$ & $561,82^{\mathrm{tn}} \pm 18,23$ & $361,74^{\mathrm{B}} \pm 6,76$ & $1,55^{\mathrm{AB}} \pm 0,03$ & $332,78^{\mathrm{B}} \pm 2,62$ \\
\hline $\mathrm{P} 2$ & $569,19^{\text {tn }} \pm 24,18$ & $378,90^{\mathrm{A}} \pm 10,31$ & $1,50^{\mathrm{B}} \pm 0,05$ & $360,53^{\mathrm{A}} \pm 12,09$ \\
\hline Rataan & $572,95 \quad \pm 15,50$ & $365,64 \pm 3,76$ & $\pm 0,04$ & 331,31 \\
\hline
\end{tabular}

Keterangan : tn : tidak berbeda nyata

superskrip dengan huruf kapital yang berbeda ke arah kolom menunjukkan pengaruh sangat nyata $(\mathrm{P}<0,01)$

\section{Konsumsi Pakan}

Konsumsi pakan adalah kemampuan untuk menghabiskan sejumlah pakan yang diberikan kepada ternak dengan tujuan untuk dapat hidup, meningkatkan pertumbuhan bobot badan dan berproduksi. Konsumsi pakan dihitung berdasarkan selisih antara jumlah pakan yang diberikan dengan jumlah sisa dan ransum yang terbuang. Hasil penelitian yang telah dilakukan diperoleh rataan konsumsi ayam broiler selama penelitian dapat dilihat pada Tabel 1.

Rataan konsumsi pakan ayam broiler selama penelitian berkisar antara 561,82-585,61 (g/ekor/minggu). Analisis ragam menunjukkan bahwa pengaruh perlakuan tidak berpengaruh 
nyata $(\mathrm{P}>0,05)$ terhadap konsumsi pakan ayam broiler. Hal ini disebabkan karena pemberian probiotik yang ditambahkan pada pakan dalam jumlah sedikit yaitu $0,3 \%$ dari total pakan yang diberikan per hari, sehingga penyerapan nutrien tidak dapat dilakukan secara maksimal, selain itu, probiotik bukan merupakan sumber nutrien sehingga tidak memberikan dampak yang signifikan terhadap peningkatan konsumsi pakan. Hal ini sesuai dengan pernyataan Manin et al. (2010), yang menyatakan bahwa probiotik bukanlah sumber nutrien sehingga keberadaannya tidak memberikan dampak yang signifikan terhadap peningkatan intake nutrien, selanjutnya hasil-hasil penelitian sebelumnya dikatakan bahwa pada pemberian probiotik tidak mempengaruhi konsumsi pakan secara signifikan.

\section{Pertambahan Bobot Badan}

Pertambahan bobot badan ayam broiler dalam penelitian ini diperoleh dari hasil penimbangan bobot badan akhir dikurangi dengan bobot badan awal penimbangan. Pengukuran bobot badan dilakukan dengan selang waktu 7 hari sekali. Hasil penelitian yang telah dilakukan diperoleh rataan pertambahan bobot badan ayam broiler selama penelitian dapat dilihat pada Tabel 1.

Rataan pertambahan bobot badan ayam broiler selama penelitian berkisar 357,90 - 378,90 (g/ekor/minggu). Analisis ragam menunjukkan bahwa pengaruh perlakuan berpengaruh sangat nyata $(\mathrm{P}<0,01)$ terhadap pertambahan bobot badan ayam broiler. Hasil uji Duncan menunjukkan bahwa pemberian pakan ditambah dengan BAL terenkapsulasi mempengaruhi pertambahan bobot badan secara signifikan pada minggu I dan II pengaruh pemberian pakan ditambah BAL terenkapsulasi berpengaruh sangat nyata $(\mathrm{P}<0,01)$ terhadap pertambahan bobot badan ayam broiler.

Hal ini dikarenakan infeksi E. coli pada ternak diberikan pada hari ke-5 umur ayam broiler sehingga penambahan BAL terenkapsulasi pada pakan berfungsi mengendalikan E. coli yang terdapat pada saluran pencernaan ayam broiler yang terinfeksi E. coli tersebut. Sementara itu pada minggu III, IV, dan V pengaruh pemberian pakan yang ditambah BAL terenkapsulasi tidak berpengaruh nyata $(\mathrm{P}>0,05)$ terhadap pertumbuhan bobot badan dikarenakan infeksi $E$. coli yang diberikan hanya sekali yaitu pada hari ke 5 umur ayam broiler seperti tersebut diatas, sehingga salah satu fungsi probiotik yaitu mengendalikan mikroorganisme pathogen pada tubuh inang tidak bekerja secara maksimal akibat tidak adanya infeksi yang diberkan. Hal ini sesuai dengan pernyataan Fuller (1992), yang menyatakan bahwa probiotik menyeimbangkan populasi mikrobia pada saluran pencernaan, 
mengendalikan mikroorganisme pathogen pada tubuh inang dan lingkungan, menstimulasi imunitas inang dan memiliki kemampuan meredukdi polutan.

Hasil penelitian juga menunjukkan penambahan BAL terenkapsulasi lebih baik daripada penambahan BAL tanpa enkapsulasi, namun penambahan BAL tanpa enkapsulasi lebih baik daripada pakan yang tidak diberi BAL. Hal ini disebabkan oleh adanya suplementasi probiotik dalam ransum dapat meningkatkan pertambahan bobot badan, pemanfataan nutrien serta kecernaan nitrogen dan fosfor. Hal ini sesuai dengan pernyataan Piao et al. (1999), yang menyatakan bahwa suplementasi probiotik dalam ransum dapat meningkatkan pertambahan bobot badan, pemanfataan nutrien serta kecernaan nitrogen dan fosfor. Konsumsi nutrien yang meningkat diikuti dengan kecernaan yang tinggi menyebabkan jumlah nutrien yang tercerna dan terserap semakin banyak. Ilustrasi tentang pemberian bakteri asam laktat terhadap bobot badan mingguan tertera pada Gambar 1.

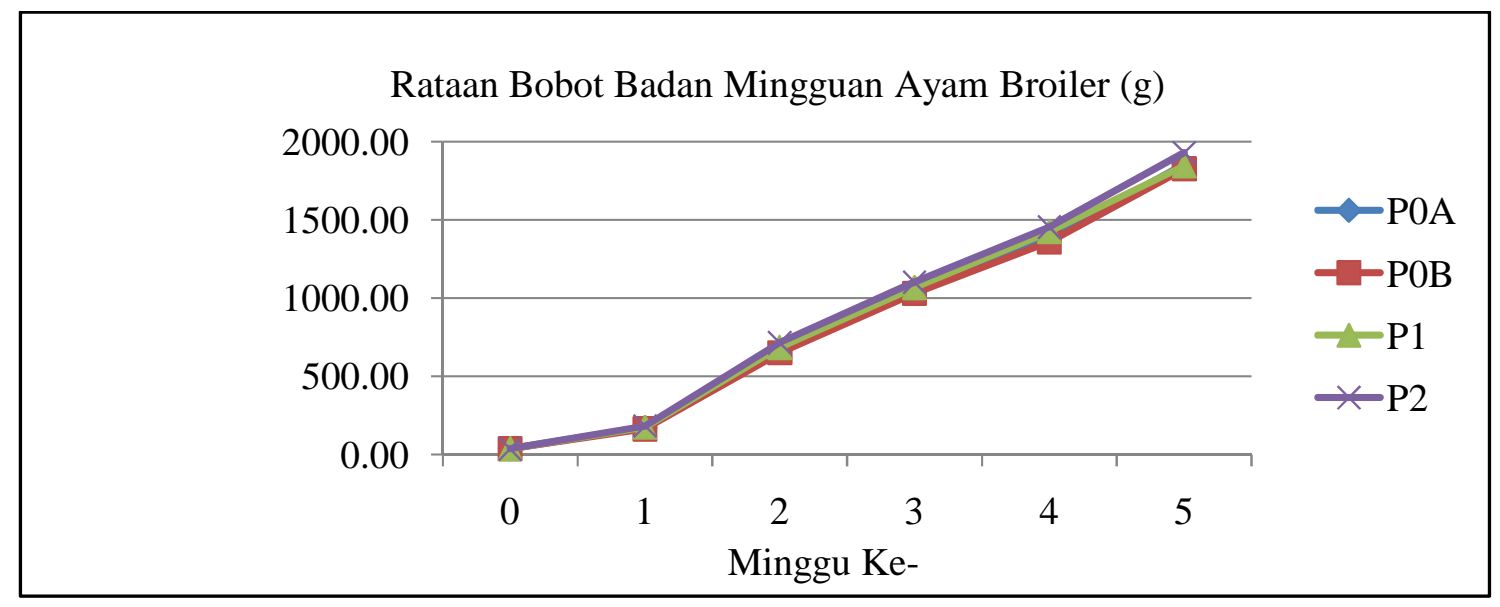

Gambar 1. Grafik Rataan Bobot Badan Mingguan Ayam Broiler

\section{Konversi Pakan}

Konversi pakan dihitung berdasarkan perbandingan konsumsi pakan dengan pertambahan bobot badan yang dihasilkan selama 1 minggu. Dari hasil penelitian yang telah dilakukan diperoleh rataan konversi ayam broiler selama penelitian dapat dilihat pada Tabel 1.

Rataan konversi pakan ayam broiler selama penelitian berkisar antara 1,50-1,62. BAL terenkapsulasi lebih efisien dibandingkan dengan BAL tanpa enkapsulasi. Namun BAL tanpa enkapsulasi lebih efisien dibandingkan dengan pakan tanpa diberi BAL. Probiotik diduga dapat meningkatkan efisiensi penggunaan pakan. Hal ini sesuai dengan pernyataan Wiryawan 
et al. (2005), yang menyatakan bahwa probiotik bentuk enkapsulasi lebih efisien yang ditandai dengan angka konversi pakan ayam pedaging yang mendapat perlakuan bentuk enkapsulasi lebih rendah.

Hasil analisis ragam terhadap nilai konversi pakan menunjukkan bahwa pengaruh perlakuan berpengaruh sangat nyata $(\mathrm{P}<0,01)$. Hasil uji Duncan menunjukkan bahwa pemberian pakan ditambah dengan BAL terenkapsulasi mempengaruhi konversi pakan secara signifikan. Terlihat pada Tabel 1. Pengaruh pemberian pakan ditambah BAL terenkapsulasi berpengaruh sangat nyata $(\mathrm{P}<0,01)$ terhadap konversi pakan ayam broiler. Hal ini dikarenakan peran probiotik sebagai penyeimbang mikrobia dalam saluran pencernaan dapat menjadikan efisiensi penggunaan pakan.

Sejalan dengan pernyataan Bird (2006), yang menyatakan bahwa peningkatan viskositas usus dapat disebabkan oleh jumlah bakteri yang tidak seimbang di usus. Efek negatif yang ditimbulkan jika viskositas usus halus tinggi yaitu dapat mengurangi efisiensi pencernaan, akibatnya peningkatan nutrien tercerna yang diikuti dengan peningkatan energi metabolis akan meningkatkan biosintesis jaringan daging sehingga pertambahan bobot badannya meningkat. Peningkatan konsumsi pakan yang diiringi dengan pertambahan bobot badan yang meningkat akan menyebabkan konversi pakan menurun dan efisiensi ransum meningkat (Hsu et al., 2000).

\section{Indeks Penampilan (IP)}

Penghitungan indeks penampilan (IP) merupakan salah satu parameter keberhasilan pemeliharaan ayam broiler, sedangkan pencapaian kinerja pemeliharaan ayam broiler yang utama dilakukan melalui pengukuran 5 (lima) parameter,yaitu : 1) Pencapaian bobot badan atau Body Weight (BW); 2) Tingkat konsumsi pakan atau Feed Conversion Ratio (FCR); 3) Rata-rata Umur atau Age saat dipanen (A/U); 4) Tingkat kematian atau Mortality (M); 5) Nilai Produksi (NP)/Indeks Penampilan (IP). Pengukuran dan penilaian kelima parameter kinerja pemeliharaan mencerminkan kualitas pemeliharaan ayam broiler (Jatmiko, 2006).

Rataan pertambahan bobot badan ayam broiler selama penelitian berkisar 357,90 - 378,90 (g/ekor/minggu). Analisis ragam menunjukkan bahwa pengaruh perlakuan berpengaruh sangat nyata $(\mathrm{P}<0,01)$ terhadap pertambahan bobot badan ayam broiler. Hasil uji Duncan menunjukkan bahwa pemberian pakan ditambah dengan BAL terenkapsulasi mempengaruhi indeks penampilan secara signifikan. Pada Tabel 1 menunjukkan bahwa rataan indeks penampilan ayam broiler selama penelitian sebesar 331,31 serta indeks 
penampilan terbaik pada penambahan BAL terenkapsulasi sebesar 360,53 dapat dilihat pada Gambar 2.

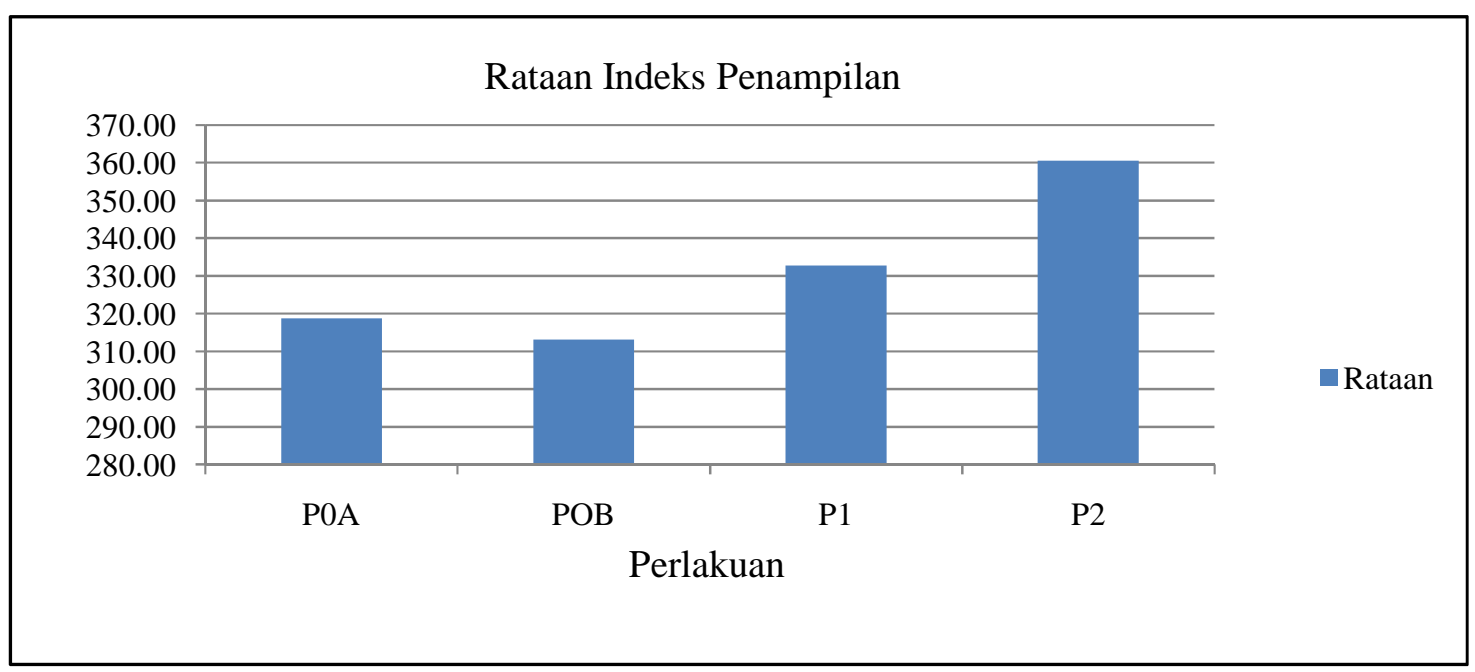

Gambar 2. Grafik Rataan Indeks Penampilan Ayam Broiler

Berdasarkan angka rataan indeks penampilan sebesar 331,31 diketahui bahwa indeks penampilan pada pemeliharaan ayam broiler dalam penelitian ini telah mencapai standar indeks penampilan yang baik yaitu di atas 300. Hal ini sesuai dengan pernyataan Jatmiko (2006), yang menyatakan bahwa standar indeks penampilan (IP) yang baik ialah di atas 300 . Oleh karena itu, semakin tinggi nilai IP maka semakin berhasil suatu peternakan ayam broiler tersebut.

Penilaian ini sangat berguna bagi peneliti untuk mengetahui sejauh mana keberhasilan pemeliharaan ayam broiler yang dilakukan oleh peneliti. Hal ini sejalan dengan pernyataan Jatmiko (2006), yang menyatakan bahwa pengukuran dan penilaian ini sangat berguna bagi peternak dan perusahaan untuk mengetahui sejauh mana keberhasilan produksi pemeliharaan ayam broiler dari suatu farm yang di kelola, dibandingkan dengan standar yang di terapkan oleh perusahaan.

\section{KESIMPULAN}

Penggunaan bakteri asam laktat (BAL) terenkapsulasi tidak memberikan pengaruh nyata terhadap konsumsi, namun memberikan pengaruh berbeda sangat nyata terhadap peningkatan pertambahan bobot badan ayam broiler dan indeks penampilan ayam broiler, serta penurunan konversi pakan ayam broiler. Dampak penggunaan bakteri asam laktat 
(BAL) terenkapsulasi sangat signifikan ketika dilakukan infeksi E.coli melalui uji tantang pada ayam broiler.

\section{DAFTAR PUSTAKA}

Acros, Arbor. 2009. Broiler Management Guide. Aviagen Incorporated Cummings Research Park. Huntsville, USA.

Bird, J.N. 2006. Performance Improvement Following Enzyme Supplementation of Wheat and Barley Poultry Diets. Asia Pacific Vitamins and fine Chemical, Animal Nutritionand Health.

Cavazzoni, V., A.Adami and C. Castrovilli, 1998. Performance of broiler chickens suplemented with Bacillus coagulans as probiotic.

Fuller, R. 1992. History and development of probiotic. Dalam : Fuller,R. (Ed). Probiotic The Science Basic. Chapman and Hall, London.

Harahap, A. E. 2011. Kajian Kualitas dan Kuantitas Bakteri Asam Laktat Silase Ransum Komplit Hasil Samping Jagung yang Dikapsulasi Menggunakan Bahan dan Metode Berbeda. AGRINAK. Vol . 01 No. 1 September 2011: 48:51 ISSN: 2088-8643 48. Fakultas Pertanian dan Peternakan Universitas Islam Negeri Sultan Syarif Kasim Riau.

Hogan, S. A., Mc.Namee, B. F., O’Riordan E. D., and O’Sullivan, M. 2001. Emulsification and Microencapsulation Properties of Natrium Caseinate/Carbohydrate Blends. Int. J. Dairy 11: 137-144.

Hsu, J.C., L.I.Chen and B. Yu.2000. Effect of levels of crude fiber on growth performances and intestinal carbohydrase of domestic gosling. Asian-Aust. J. Anim. Sci. 13 (10) : $1450-1455$.

Jatmiko. B. 2006. Persepsi Pengusaha Atas Pengaruh Kesediaan Faktor-Faktor Produksi Terhadap Laba. Studi Kasus Pada Industri Ayam Ras Broiler Model Plasma di Kab. Semarang. Program Pasca Sarjana. Program Studi Magister Manajemen. Universitas Muhammadiyah. Surakarta.

Manin F. E. Hendalia, Yusrizal dan Yatno. 2010. Penggunaan Sinbiotik Yang Berasal Dari Bungkil Inti Sawit Dan Bakteri Asam Laktat Terhadap Penampilan Dan Status Kesehatan Ternak Ayam Broiler. Penelitian Hibah Bersaing Tahun 2010. Fakultas Peternakan. Universitas Jambi.

Piao, X.S., I.K. Han, J.H. Kim, W.T. Cho W.H. Kim and C. Liang. 1999. Effect of kemzyme, phytase, and yeast supplementastion on the growth performance and pollution reduction of broiler chick. Asian-Aust. J. Anim. Sci. 12 (1) : 36-41.

Wiryawan K.G., M. Sriasih, dan I. D. P. Winata. 2005. Penampilan Ayam Pedaging yang diberi Probiotik (EM-4) sebagai Pengganti Antibiotik. Fakultas Peternakan, Universitas Mataram, Mataram 83125 NTB 20008. 